\title{
The importance of gluten exclusion in the management of Hashimoto's thyroiditis
}

\author{
Paulina Ihnatowicz ${ }^{1, A-D, F}{ }^{\infty}$, Paweł Wątor ${ }^{2, A-D, F} \oplus$, Małgorzata Ewa Drywień ${ }^{1, A, D-F}$ \\ ${ }^{1}$ University of Life Sciences, Warsaw, Poland \\ ${ }^{2}$ University of Agriculture, Kraków, Poland \\ A - Research concept and design, B - Collection and/or assembly of data, C - Data analysis and interpretation, \\ $D$ - Writing the article, E-Critical revision of the article, F- Final approval of article
}

Ihnatowicz P, Wątor P, Drywień ME. The importance of gluten exclusion in the management of Hashimoto's thyroiditis. Ann Agric Environ Med. 2021; 28(4): 558-568. doi: 10.26444/aaem/136523

\begin{abstract}
Introduction and objective. There is a growing interest in a gluten-free diet (GFD) in the management of various autoimmune diseases, including Hashimoto's thyroiditis (HT). Even medical professionals claim that gluten elimination may improve a patient's treatment. Some studies suggest a relationship between gluten intake and HT development or progression. The aim of the study was to analyze and describe available knowledge regarding the effect of gluten or a gluten-free diet on thyroid autoimmunity in HT with or without celiac disease.

Brief description of the state of knowledge. Potentially applicable records were obtained through review and analysis of the PUBMED (MEDLINE) and Google Scholar database by using the following phrases: 'hypothyroidism gluten', 'Hashimoto gluten' and 'thyroiditis gluten'. If a record focused on the subject by title and abstrakt, the full paper was screened. Authors' scientific achievements and references of eligible records were screened for possibly omitted studies. The review was focused only on human studies.

Discussion. Gluten exclusion might increase the risk of HT development because of the potential nutritional deficiencies related to the low quality of gluten-free products. Gluten intake from crops grown on selenium-depleted soil increases the risk of HT development. Only a few studies suggest that GFD would be beneficial for HT patients, even without the coexistence of $\mathrm{CD}$. The strongest connection between gluten intake and thyroid destruction seems to be based on a mechanism of molecular mimicry between gut and thyroid tissue transglutaminase.

Conclusions. Studies conducted so far do not support the claim that HT patients should eliminate gluten from their diet. In view of the limited number of studies, with major limitations and ambiguous results, a gluten-free diet is not recommended.
\end{abstract}

\section{Key words}

hypothyroidism, Hashimoto's thyroiditis, gluten, thyroid peroxidase antibodies, thyroid functions

\section{INTRODUCTION}

Gluten is a common name for the group of proteins that are found in wheat, barley, rye, and contaminated oatproducts. Because it is an autogenous antigen in celiac disease (CD), those patients must eliminate gluten from their diet to avoid autoimmune reactions [1]; however, 'pure oat' is tolerated by most of CD patients [2]. The common characteristic of the disease is the presence of antibodies directed against immunogenic gliadin peptides, as well as tissue transglutaminase itself [1]. However, a gluten-free diet (GFD) is quite difficult to follow and it contributes to the potential risk of nutritional deficiencies and insufficient intake of fibre $[3,4,5]$. It has been reported that people on GFD consume an inadequate amount of vitamins $B$ and $\mathrm{C}$, folates, iron, zinc, and magnesium $(\mathrm{Mg})$. Especially for the latter, a GFD may deteriorate $\mathrm{Mg}$ deficiency and constrict HT therapy. This might be specifically in the case of a mitochondrial background of the disease in which $\mathrm{Mg}$ supplementation was found to be therapeutic $[6,7,8]$. Moreover, gluten-free products may have a higher glycaemic load and index than those containing gluten. In 2018, the Polish experts from the POLSPEN group stated their position

Address for correspondence: Małgorzata Ewa Drywień, Warsaw University of Life Sciences, Nowoursynowska 159 c, 02-776, Warsaw, Poland

E-mail: malgorzata_drywien@sggw.edu.pl

Received: 16.03.2021; accepted: 10.05.2021; first published: 28.05.2021 about the recommendation of GFD in HT. Given the fact that the aspect of the importance of gluten elimination in HT merits a more explicit discussion than in their statement, this review focuses particularly on this matter.

$\mathrm{HT}$ is also an autoimmune disease, the common characteristics of which result from the infiltration into the thyroid gland by lymphocytes and the production of antibodies directed against thyroid peroxidase (anti-TPO), thyroglobulin (anti-TG) and thyrotropin receptor (TRAb, in only $\sim 10 \%$ of patients) [1]. Unlike CD, no food compound consumption triggers an immune response in HT. Among the nutritional risk factors for the development of HT are iodine deficiency and excess, selenium and vitamin D deficiency, but not gluten intake [9]. Selenium (Se) seems to be one of the most important nutritional factors affecting thyroid metabolism and the risk of autoimmunity development. Despite that, the thyroid gland is well supplied with Se, even at a deficiency state [10] a low intake of it significantly increases the risk of HT incidence [11]. The reason is that Se is a part of multiple selenoproteins associated with immune function and the thyroid gland. They are iodothyronine deiodinases responsible for thyroid hormones synthesis and glutathione peroxidases implicated in antioxidant defence of thyrocyte from hydrogen peroxide. The latter is naturally produced as a byproduct during thyroid hormones production and may cause oxidative damage and cell death. Thus, Se supplementation trials have been successful in HT, 
and Se deficiency is a relevant risk factor of HT, although studies are inconclusive [10]. Se content in foodstuffs reflects the Se content in the soil; therefore, crops, cereal, and glutencontaining products may be either an important source of $\mathrm{Se}$, or the cause of its deficiency. Thus, gluten intake may be associated with HT incidence dependent of the Se content of food products included in the diet [11].

Moderate alcohol consumption is also a protective factor for hypothyroidism with no difference between wine and beer. Although the mechanism responsible is still not known and studies indicate only an association, such a finding is supported by several studies. Alcohol alters the function of either natural cell killers or both Th1- and Th2-mediated immunity $[12,13]$. But there is also a possibility that it is caused by an increased Se intake with alcohol products. Moreover, brewing yeast increases Se bioavailability as it biotransforms inorganic sodium selenite to its bioactive organic form [14]. In genetically predisposed individuals, exposure to nutritional and environmental factors, such as nutrients excess or deficiency, stress, smoking, infections and medication, develop autoimmune HT. Both CD and HT share common risk factors, among them, a genetic background has been proved to be significant [9].

An interesting mechanism of action linking gluten intake in celiac patients with a higher risk of thyroid autoimmunity development is molecular mimicry between gut and thyroid tissue transglutaminase. In celiac disease, this protein is a CD-related autoantibody [15], except that other possible causes connecting CD with HT are deficiencies in nutrients caused by disrupted gastrointestinal health or deficient GFD. Some of the nutrients are necessary for thyroid function, and thus might be a cause of higher HT incidence in CD patients.

Most studies have focused on the incidence of both diseases and the impact of GFD. Prior to the preparation of the current review, only two control studies had been performed on a gluten exclusion diet in HT patients who had not been diagnosed as CD patients. The obtained results support the claim that GFD might be helpful in HT disease, at least in the studied population. Additionally, in the last years only three case-study surveys have been published. The strongest limitation of these studies is that gluten exclusion is a part of an integrative approach, and it cannot be concluded that GFD had any effect on the patient's outcomes. Nevertheless, because of the literature gap in this area, it was decided to include those papers in the present review.

The described scientific knowledge indicates whether a GFD may be beneficial for thyroid function and thyroid autoimmunity in HT with or without CD. The coexistence of both diseases and potential causes were studied. For the current literature review, the following phrases were used: 'hypothyroidism gluten', 'Hashimoto gluten' and 'thyroiditis gluten' in the Google Scholar scientific browser and National Library of Medicine PubMed until November 2020. To increase the scope of the revised document and to avoid the possibility of omitting papers, both the scientific achievements of all authors and references in their publications were included. The authors focused only on human studies. Because of the lack of sufficient studies done on the subject, the current review is not a systematic review and does not include all studies on the subject. A total of found 64 papers were found in which HT patients were studied for prevalence of $\mathrm{CD}$ titers, or $\mathrm{CD}$ patients for antithyroid titers. In some of those papers, the effect of gluten exclusion was studied.
Most of the studies were observational, of which only a few were case reports on HT patients in which GFD was a part of a broader medical intervention. Two are described in detail in the presented review to indicate a possible dietary/ interventional approach to HT patients. There were also only two controlled studies on the subject, which are described later in the review, while other articles studied the effect of GFD on thyroid autoimmunity. It was not considered necessary to include all the studies collected for this review, and to prevent any bias, the studies with extreme results have been described, taking into consideration studies focused only on few patients as not valuable for description in the paper. A review of the latest studies is included at the end of the presented review (Tab. 3, 4).

Celiac disease and Hashimoto's thyroiditis. HT is the most common autoimmune disease concurring with CD. Both diseases have a significant proportion of the same risk factors but the most significant is the genetic background [9]. One of the autoantibodies produced in CD is the intestine tissue transglutaminase (tTG2) which deaminates gliadin, hence the measurement of its level is used for the diagnosis [1]. Due to the presence of the tTG2 in tissues other than intestinal, autoimmune cross-reactions with other tissues are possible. This enzyme is also found in the thyroid gland and it was suggested that it is one of the reasons for CD patients becoming more prone to HT, a hypothesis that was confirmed by the immunofluorescence study by Naiyer et al. [15] in which indirect staining of follicular cells and the extracellular matrix of the thyroid have bound anti-tTG2 antibodies. Which suggests that CD patients with positive anti-tTG titers may have an increased risk of developing hypothyroidism due to an autoimmune cross-reactivity [15]. On the other hand, the results of intestinal biopsies from $\mathrm{HT}$ patients indicate a higher frequency of $\mathrm{CD}$ in comparison with healthy participants, particularly in the case of children. In a meta-analysis, in which both autoimmune thyroid diseases, HT and GravesBasedow disease were included, the $\mathrm{CD}$ was diagnosed in one out of 62 patients [16]. The authors indicated that thyroid autoimmune patients should be examined for CD comorbidity [16], which is consistent with the recommendations of the European Society for Gastroenterology, Hepatology and Nutrition (ESPGHAN) [17].

Based on current studies (Tab. 1), 7.9\% [18] and 6.4\% [19] of HT child patients had increased CD-related antibodies in comparison to the control groups in which either none [16] or $3.3 \%$ were found to be serologically positive [19]. Such differences are also similar for HT adult patients as CDrelated antibodies were diagnosed in $5.9 \%-22.5 \%$ [19, 20, 21]. Moreover, Riseh et al. [21], based on $40 \mathrm{HT}$ patients and a healthy age-matched control group, found in the ordinal regression model that IgG-anti-tTG and IgA-anti-gliadin were significant predictors for thyroid antibodies [21]. In another study, Marwaha et al. [19] found that increases of anti-tTG and anti-GAD (diabetes-associated antibody) were associated with the anti-TPO level.

Although further studies have been conducted from the aspect of the occurrence of antibodies related to HT in CD patients and vice versa, there was no need to cite them all in the current review and only those significant for the subject are described.

Celiac patients should also be monitored for antithyroid antibodies positivity (Tab. 2) because up to $41 \%$ of CD 
Table 1. CD-related antibodies in HT patients [\%]

\begin{tabular}{|c|c|c|c|c|}
\hline Antibody tested & $\begin{array}{l}\text { HT children } \\
\text { patients [\%] }\end{array}$ & $\begin{array}{c}\text { Control } \\
\text { group [\%] }\end{array}$ & Comment & Ref. \\
\hline $\lg \mathrm{A}$-anti-tTG & 7.9 & 0 & - & 18 \\
\hline Anti-tTG & 6.4 & 3.3 & $\begin{array}{l}\text { Anti-tTG antibodies level } \\
\text { increased with anti-TPO. }\end{array}$ & 19 \\
\hline Anti-tTG & 7.4 & 3.5 & $\begin{array}{l}\text { Anti-tTG antibodies level } \\
\text { increased with anti-TPO. }\end{array}$ & 19 \\
\hline $\operatorname{lgA}$-anti-tTG & 5.9 & 0.8 & \multirow{5}{*}{$\begin{array}{l}\text { IgG-anti-tTG and IgA-anti- } \\
\text { gliadin were significant } \\
\text { predictors for thyroid } \\
\text { antibodies }\end{array}$} & 20 \\
\hline lgG-anti-tTG & 15 & 7 & & 21 \\
\hline $\lg \mathrm{A}$-anti-tTG & 22.5 & 17 & & 21 \\
\hline IgG-anti-gliadin & 9.5 & 5 & & 21 \\
\hline IgA-anti-gliadin & 15 & 12 & & 21 \\
\hline
\end{tabular}

children, compared to $3.6 \%$ of the control, were positive [22]. Meloni et al. found that the prevalence of HT in the CD child patients in Sardinia was about four times greater than in the age-matched control group [23]. From $324 \mathrm{CD}$ patients, 34 were positively tested for antithyroid antibody titers and 23, of whom 34 followed the GFD. This indicates that the autoimmune thyroid is independent of gluten exposure [23]. Considering CD adult patients, $10.1 \%$ compared to $1.6 \%$ from the control group were diagnosed for autoimmune hypothyroidism, although the differences in circulating thyroid antibodies were not statistically significant between groups [24]. In other studies $29.7 \%$ vs $9.6 \%$ [25] and $30.5 \%$ vs $9.7 \%$ of CD patients vs control were anti-TPO positive [26], or $10.1 \%$ had thyroid dysfunction compared to $3.3 \%$ from the control group [24]. Compared to healthy, age- and gender-matched people, adult patients were at higher risk of developing HT [27]. This was also proved in child CD patients compared to an age-matched control group [23]. A contradictory result is provided by Guariso et al. [28], who followed-up $170 \mathrm{CD}$ children for $47+/$ - 31 months in complete remission on GFD. In comparison to the control group, the obtained results suggested that GFD may delay or prevent the onset of another autoimmune disease, including HT.

Thyroid autoantibodies may fluctuate over time in the natural course of the disease, even more so, a hyperthyroid patient can become hypothyroid and vice versa [29]. To exclude the possible improvement of thyroid autoimmunity during GFD, other parameters, such as serum TSH and the ultrasonographic pattern of the thyroid, should be taken into account.

Possible causes of coexistence of $C D$ and HT. There are direct and indirect possible causes for the coexistence of both diseases (Fig. 1), the most significant of which is the genetic background. Although the exact mechanism responsible is not known, two mechanisms involving the human leukocyte antigen (HLA) system are discussed. One of the functions of HLA molecules is to bind antigens and display them on the cell surface for recognition by T-cells. It is suggested that different HLA alleles differ in affinities for peptides from autoantigen, and thus when presented can be recognized by T-cells that have escaped tolerance. There are two possible mechanisms responsible for susceptibility to both HT and CD in HLA class II. The first refers to the HLA binding groove structure of class II DR3 and DQB1 molecules with linkage disequilibrium. They have different binding grooves but together are present in antigen-presenting cells. The second
Table 2. HT-related antibodies in CD patients.

\begin{tabular}{|c|c|c|c|c|}
\hline Antibody tested & $\begin{array}{l}\text { CD children } \\
\text { patients [\%] }\end{array}$ & $\begin{array}{l}\text { Control } \\
\text { group [\%] }\end{array}$ & Comment & Ref. \\
\hline $\begin{array}{l}\text { Antimicrosomal } \\
\text { (Anti-TMA) }\end{array}$ & 14 & 0 & \multirow{3}{*}{$\begin{array}{l}\text { Collectively, the presence of } \\
\text { elevated titers (anti-TMA and/ } \\
\text { or anti-TPO and/or anti-TG) } \\
\text { was demonstrated in } 41.1 \% \\
\text { CD patients vs } 3.6 \% \text { in control } \\
\text { group. Anti-TMA is rarely } \\
\text { studied in HT. }\end{array}$} & \multirow{3}{*}{22} \\
\hline Anti-TG & 32.3 & 3.5 & & \\
\hline Anti-TPO & 11.7 & 3.5 & & \\
\hline $\begin{array}{l}\text { Anti-TPO and } \\
\text { anti-TG }\end{array}$ & 10.5 & 2.9 & $\begin{array}{l}\text { Most of the diagnosed } \\
\text { patients were on GFD, } \\
\text { indicating that gluten } \\
\text { exclusion does not protect } \\
\text { from thyroid autoimmunity. }\end{array}$ & 23 \\
\hline Anti-TPO & 11.4 & 5.1 & \multirow{3}{*}{$\begin{array}{l}10.1 \% \text { CD patients vs } \\
1.6 \% \text { from control group } \\
\text { were diagnosed for } \mathrm{HT} \\
\text { and } 10.1 \% \text { vs } 3.3 \% \text { for } \\
\text { SHT. The differences in } \\
\text { thyroid antibodies were } \\
\text { not statistically significant. } \\
\text { Anti-TPO and anti-TMA in CD } \\
\text { were associated with an echo } \\
\text { pattern of thyroid. }\end{array}$} & \multirow[b]{3}{*}{24} \\
\hline Anti-TMA & 17.7 & 15.7 & & \\
\hline Anti-TG & 8.8 & 5.1 & & \\
\hline Anti-TPO & 29.7 & 9.6 & - & 25 \\
\hline Anti-TPO & 30.5 & 9.7 & - & 26 \\
\hline
\end{tabular}

suggestion is that different antigen-binding structures can be expressed together and accommodated. Some studies have demonstrated a concurrent susceptibility for both HT and CD in Caucasians and Asians. Besides HLA genes, the coexistence of different autoimmune diseases could also be explained by aberrant immune regulation by susceptible genes, e.g. that are involved in the activation of Treg cells [30]. Among others listed in the literature are the following: - Selenium: malabsorption of nutrient sources, including Se, is observed in CD [31, and in the Polish population [32]. Selenium, as one of them, is associated with an increased risk of the development and progression of HT [33]. Selenium malnutrition was often observed in HT patients [10].

- Vitamin D: similar to Se in CD, the absorption of vitamin D from food may be reduced [34]. It plays an important role in the functioning of the immune system and in autoimmune processes, e.g. through increasing the body's tolerance to its tissues and by anti-inflammatory properties [33]. Among Polish HT patients of both genders, both a too low food intake $[35,36]$ and too low vitamin D level in the blood were observed $[35,37,37]$.

- Iron: a component for which the absorption may be reduced due to CD [34], resulting in an increased risk of anaemia in this group by as much as $70 \%$ [38]. Iron participates in the synthesis of thyroid hormones [39], and its deficiency may reduce thyroid function [40, 41]. In HT, insufficient iron levels are observed in both children [42] and adults [43],

- Gut microbiota: is a part of the immune system and its disorders may stimulate autoimmune processes [44], thyroid dysfunction [45] and HT underdevelopment [46, 47].

- Gut permeability: increased intestinal permeability was associated with the development of autoimmune diseases [48] including HT [49]. This means that an excessive space in the intercellular space between enterocytes promotes the transport of inflammatory molecules, e.g. bacterial toxins, from the intestine to blood $[50,51]$. 
- Molecular mimicry: due to the presence of the tTG in the thyroid gland, this gland may be destroyed as a result of a cross-reaction in CD [15]. Patients with thyroid autoimmunity should be tested for anti-tTG antibodies [52]. When the anti-tTG test is positive, gluten elimination may be beneficial for thyroid autoimmunity [36].

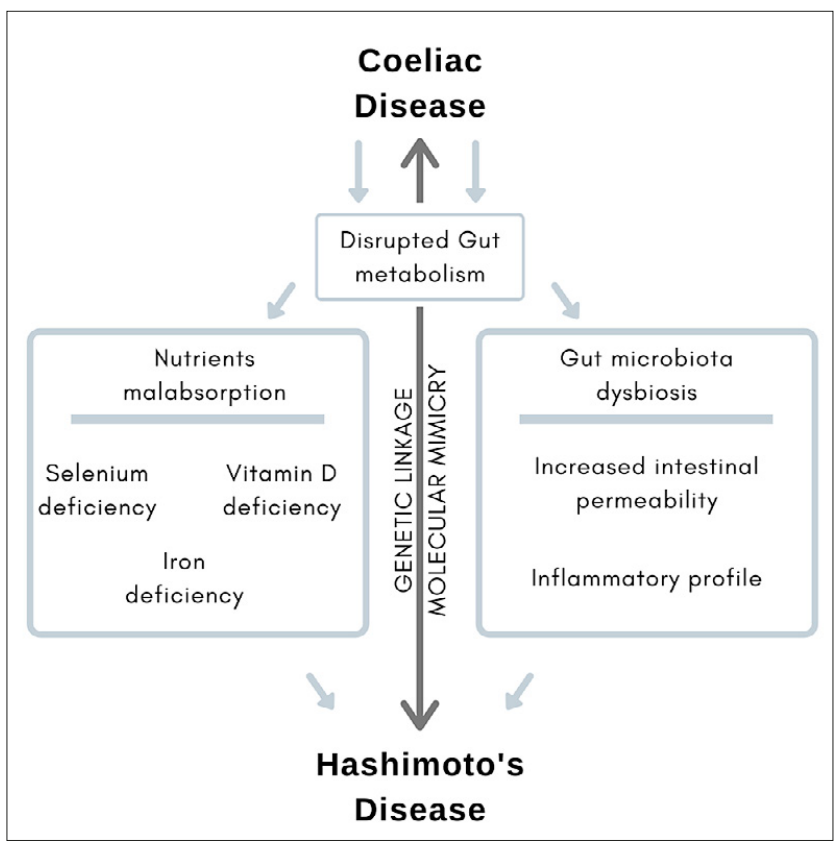

Figure 1. Possible causes of the coexistence of both diseases. Light grey arrows: the indirect connection between diseases. Dark grey arrows: direct connections

The most significant linkage for CD and HT is the genetic background, thus genetically susceptible patients are at increased risk of developing other autoimmune diseases. However, the main reason for overlapping autoimmune diseases is the misregulation of regulatory $\mathrm{T}$ cell development that suppresses the autoimmune reactions of effector cells. Among other possible causes are deficiencies in nutrients caused by disrupted gut metabolism and nutrients malabsorption observed in CD. Those nutrients, e.g. Se or iron, are necessary for thyroid metabolism, and their deficiencies might increase the risk of developing autoimmune hypothyroidism. Gut microbiota dysbiosis observed in $\mathrm{CD}$ is also associated with increased gut permeability and inflammatory processes. Both are known to be linked with autoimmune diseases. Besides that, anti-tTG recognizes tTG2 in the thyroid gland.

The presence of autoantibodies is not indicative of the disease as they are present in all normal tissues. Naturally occurring autoantibodies are part of metabolism responsible, e.g. for cell debris clearance or removing damaged cells. Thus, an autoimmune disease is a matter of the escalation of already existing autoimmune responses and loss of self-tolerance [53]. One of the main reason for this, and as a result of the overlapping of autoimmune diseases, is the misregulation of the development of either natural regulatory $\mathrm{T}$ cells (nTreg) in the thymus (central tolerance) and/or adaptive/ induced Treg (iTreg) cells in the second organs (peripheral tolerance), and/or a deficiency in their count or function $[54,55]$. Regulatory $\mathrm{T}$ cells (Treg) are immunoregulatory lymphocytes that mediate peripheral tolerance, and their role is to suppress the immune response of conventional $\mathrm{T}$ cells to environmental antigens. As they limit immune response, they act anti-inflammatory what is beneficial for patients with inflammatory or autoimmune diseases. Other T cells, B lymphocytes and innate immune cells, are also implicated in immune tolerance [56]. In a comment to Sudhir Paul's opinion that 'there is so much, that can go wrong (...)' [57] we need to know more about where it can go wrong, how it happens, and how we can deal with it [55]. The question arises, for example, whether a gut disruption in celiac disease yields to autoimmune thyroid disease through foreign and self-nucleic acids or damage and pathogen-associated molecular patterns? It is known that those molecules are involved in thyroid autoimmunity exacerbation through toll-like receptors [58].

Another issue is the existence of environmental agents. Based on twins studies, it is known that about half [59] or even three-quarters [60] of the risk of developing autoimmunity accounts for genetic traits, and thus the other part concerns non-genetic factors. Those are, e.g. endocrine disruptors like bisphenol A, F, S, drugs, heavy metals, viruses, among others $[61,62]$. In susceptible subjects, they may trigger the appearance of autoimmune thyroid disease [63]. Celiac patients, like other autoimmune disease patients, are those genetically susceptible to environmental agents, which might be another explanation for the observed higher risk of thyroid autoimmunity development in CD patients [64].

Thyroid gland in patients with CD eliminating gluten. A study by Ventura et al. revealed that 13 out of $90(14.4 \%)$ individuals with CD had increased anti-TPO levels ( $>75$ $\mathrm{IU})$. The number of positive anti-TPO patients decreased from 13 to 10,6 and 2, respectively in 6,12 and 24 months after the introduction of GFD. After two years of a GFD, only two people were still anti-TPO positive, although its value decreased quite significantly in comparison with the baseline level [65]. Oderda et al. [66] also observed decreased levels of antibodies in children with CD, while a GFD was applied for 1-5 years but anti-TPO titers decreased in only two of six children, and increased in the rest. The authors suggested that early elimination may be useful to stop the development of thyroid autoimmunity at the initial stage, but it might be not helpful when thyroid autoimmunity has developed. The biggest limitation of the study was the small number of participants [66]. Toscano et al. [67] studied the presence of antithyroid and antipancreas antibodies in CD patients. The antibodies against one of the examined organs were found in 15 out of 44 subjects (34\%), whereas antithyroid antibodies, namely anti-TPO or anti-TG, were increased in seven (15.9\%) and six (13.6\%) subjects, respectively. In the subgroup of patients on GFD ( 25 out of $44,56.8 \%$ ), the frequency of positive results for antibodies directed against the pancreas or thyroid was $20 \%$ in comparison to $52.6 \%$ for patients who did not exclude gluten. The authors indicated that the molecular mimicry and the occurrence of crossreactions were the possible mechanisms responsible for their observations [67]. Toscano also referred to the Magazzu et al. study [68], in which GFD led to 'complete resolution of the [thyroid] dysfunction after two months' [67]; however, the authors of the current study were unable to find this article. Another study suggesting the link between gluten intake and autoimmune diseases is an observational study carried out in a group of 924 patients (including 178 individuals with a different immune disease than CD). Those who ate 
gluten doubled the risk of developing another autoimmune disease in comparison with gluten non-eaters. The group at the highest risk consisted of subjects who had been diagnosed previously, and those with a family history of autoimmune disease [69].

To-date, the presented review is the only research indicating a possible relationship between gluten intake by CD patients and their development of thyroid autoimmunity. Other studies, however, do not confirm the possibility of such an association. Gluten elimination may not reduce the risk of developing comorbid autoimmune diseases [70-73, for example, Cassio et al. indicated that the GFD applied for a long time ( 9 years) did not reduce the occurrence of positive results of thyroid antibodies in CD. Among 135 examined children, the number increased from 12 to $23 \%$, indicating that gluten is not so important, if at all [74].

\section{Thyroid gland in CD and HT patients eliminating gluten.} When CD and HT coexist, gluten elimination may inhibit thyroid damage or decrease anti-TPO $[66,75]$, but studies are equivocal [72]. In the study by Sategna-Guidetti et al. [75], HT occurred three times more often in 241 patients with CD (12.9\%) in comparison with the control group (4.2\%). This was related mainly to subclinical hypothyroidism (SHT) with organ dysfunction without the autoimmune component. Normalization of SHT was observed after a year only in a group following a GFD. Moreover, $5.5 \%$ of CD patients with normal thyroid function who did not exclude gluten, developed a thyroid dysfunction [75]. Contrarily, in study by Metso et al. [72], after a year on a GFD, it neither decreased the anti-TPO level nor stopped the destruction of the thyroid gland, and its volume at the end of the study was $5.6 \mathrm{~cm}^{3}$ in comparison with the initial $6.4 \mathrm{~cm}^{3}$ [72]. In Rasheed et al. study, gluten exclusion for one year had some beneficial effects on autoimmune thyroiditis in a few subjects, and maintained euthyroidism in CD child patients. They pointed out that GFD compliance did not affect the presence of antibodies as new anti-thyroid antibody-positive cases appeared [76].

\section{Thyroid gland in HT patients eliminating gluten.} Unfortunately, there is a lack of publications regarding the effect of gluten and its elimination on HT. The study by Krysiak et al. tested the effect of gluten elimination on the level of antithyroid antibodies in women with thyroid autoimmunity in the euthyroid state [35]. All the patients were anti-tTG positive without clinical symptoms of CD. They were divided into an intervention group $(n=16)$ on a GFD for six months and a control group $(n=18)$ free from intervention. Positive anti-tTG titers decreased only in patients who eliminated gluten by $62 \%(10 / 16)$, and both anti-TPO and anti-TG concentrations decreased by $24 \%$. Vitamin D increased by $25 \%$ (from 20 to $25 \mathrm{ng} / \mathrm{mL}$ ) and the secretory capacity of the thyroid gland measured with the SPINA-GT index was elevated by $15 \%$. These differences were statistically significant compared with the control group. Gluten elimination did not lead to changes in other measured indicators [35]. At the beginning of the study, anti-TPO concentration was correlated with anti-tTG, which was inversely correlated with plasma vitamin D and SPINAGT. However, at the end of the study, the values of these parameters improved and autoimmunity was reduced. In most of the patients, the decrease in thyroid antibody levels was associated with a decrease in anti-tTG antibody levels.
The most likely explanation for the results is an increase of vitamin $\mathrm{D}$ concentration in serum, which may have influenced the functions of the immune system and thyroid autoimmunity [33, 77]. However, the authors also indicated that the vitamin D level increase was too low to be fully responsible for the results [35]. Another possible cause of the changes observed is an improvement in Se nutrition [78]. Se intake was found to potentiate the effect of vitamin $\mathrm{D}$ on thyroid autoimmunity when taken together [79]. The subjects, as well as those described above, came from an area with a low intake of Se, and thus were Se-deficient [32, 80]. This may be confirmed by the low peripheral deiodinase activity at the beginning of the study; however, the lack of significant differences at the end of the study rather indicates that other mechanisms should be taken into account [35]. The authors also mentioned the results obtained in a mice study [81] and on CD patients [82] to explain the possible mechanism responsible for improving the parameters. In the studies, gluten elimination led to an improvement in the secreted cytokine profile in the anti-inflammatory direction. Although there are a few possible explanations for the obtained results, they lack sufficient evidence to support them. Krysiak et al. concluded that GFD may inhibit thyroid autoimmunity and improve its secretory capacity [35].

Due to the association of antithyroid antibodies with the development of SHT and HT [83, 84], it can be suggested that gluten elimination may delay the development of hypothyroidism in the group of euthyroid, autoimmune thyroid patients with positive anti-tTG antibody titers. It is worth mentioning that the most significant effect was observed in those whose level of antithyroid antibodies was the highest and those patients might benefit most from GFD.

Lack of changes in the Jostel index and SPINA-GD indicate no effect of gluten on thyrotropic cells producing TSH and the activity of Se deiodinases thyroid metabolizing hormones. There are a few disadvantages of the study: the low number of participants and short duration of intervention. Some questions arise: whether negative anti-tTG titer patients would benefit from a GFD? Would they benefit if they had normal vitamin D status and/or normal Se status? What results could be achieved if they had thyroid dysfunction? [35]. In another study conducted among 98 drug-naive women with HT and TSH levels between four and eight $\mu \mathrm{IU} / \mathrm{ml}$ and normal fT4 and free fT3 levels, gluten exclusion with selenomethionine $(200 \mu \mathrm{g}$ Se) intake improved thyroid function and autoimmunity after six months [85]. The participants of the study were divided into two groups, one taking Se with GFD, and the second, only on Se supplementation without additional dietary intervention. At the end of the study, 37/50 (74\%) participants on GFD achieved euthyroidism, compared to $28 / 48(58.3 \%)$ participants from the second group. Serum anti-TPO decreased more in the GFD group (by 49\%) than in the control group (34\%). In both groups, TSH and anti-TG levels decreased; however, gluten exclusion had an additive effect on anti-TPO. The authors also measured free thyroid hormones, but their levels probably did not change during the intervention as they were not mentioned in the study abstract (no full text available), but their concentrations were normal initially [85]. 


\section{CASE STUDIES}

The study conducted by Krysiak et al. [35] and Asimi et al. [85] were the only controlled studies that presented the effect of gluten elimination in HT patients without CD. Other publications are case study reports in which GFD was only a part of broader interventions. Avard et al. described a 23-year-old girl who declared decreased mood, energy loss, constant fatigue, hair loss, insomnia, and gastrointestinal problems, which intensified especially in stressful situations [86]. The feeling of fatigue along with decreased mood had appeared after a stressful vacation, which probably appeared due to a decrease in blood magnesium level as a result of stress [6]. As mentioned earlier, this mineral is essential for the proper functioning of the thyroid gland $[7,8]$. For two weeks before starting therapy, the patient excluded cereals and dairy products as a part of a paleolithic diet. It was also found that the patient consumed insufficient amounts of animal protein. A therapy intervention included the continuation of the paleolithic diet, stress management, and physical activity in the form of a 30-minute walk twice a week. Thyroid nodules that were found on the gland and Muehrcke's nails indicated zinc deficiency [87]. Serological tests revealed the level of anti-TPO antibodies above $1,000 \mathrm{IU} / \mathrm{mL}$, normal vitamin D status of $36 \mathrm{ng} / \mathrm{mL}$, and indirectly low activity of processes related to methylation [86]. Methylation processes depend on the availability of nutrients, such as folates and $B$ vitamins [89], initially and participate in epigenetic processes, including those responsible for regulating autoimmune processes [89] and thyroid autoimmunity [90, 91]. A deficiency of substrates for methylation processes leads to autoreactivity what may stimulate autoimmunity [92]. Nutritional intervention, including diet, as well as supplementation, are aimed particularly at improving the function of the immune system, namely the functions of selenoprotein and methylation along with a reduction of oxidative stress [86]. Taking into account the link between intestines health and autoimmune diseases $[93,94]$, the bowel function and tissue barrier were addressed by modulation of the intestinal microbiota through the use of probiotics to reduce inflammation [86].

The gluten exclusion was motivated by a decrease in the secretion of zonulin - an exogenous protein associated with intestinal permeability [48]. The methylation processes were supported by providing methylcobalamin, vitamins B, zinc, and Se. After 21-22 months, the symptoms were reduced and a decrease in TSH levels from 2.79 to $1.11 \mathrm{mU} / \mathrm{L}$, an increase in free T4 from 10.8 - 12 pmol/L, increase in anti-TG from 56 $-322 \mathrm{IU} / \mathrm{mL}$, and a decrease in anti-TPO titers from $>1,000-$ $295 \mathrm{IU} / \mathrm{mL}$ were observed [86]. The authors suggested that the increase of anti-TG observed after 15 months of intervention might have been a result of a natural worsening of the disease, or a diet ineffectiveness, although most important antiTPO titers decreased. The patient's subjective energy level increased from two to $6-8$ on a 10 -point visual scale. The subjective sleep quality and gastrointestinal functioning also improved [86]. It is possible that the supplementation of vitamin $\mathrm{D}$ and its blood concentration increase from 36 to $50-60 \mathrm{ng} / \mathrm{mL}$ would contribute to better results [95]. In this case, however, gluten elimination did not have any positive effects. Besides, the patient compliance to the elimination was not fully complete throughout the study. The observed changes may have resulted from improved nutrition and supplementation, and above all, environmental stress management.

A similar dietary intervention was conducted by Abbott et al., who describe 12 patients in their study who were treated with the so-called 'autoimmune protocol' [96]. This is a non-defined dietary model aimed at improving the immune system's tolerance to its tissue, and reducing the intensity of autoimmune processes. In the referred study, a modified paleolithic diet was applied, while cereals, dairy products, and food additives were eliminated. The intake of vegetables, fruits, and nuts was increased. The report focused on the improvement of the state of intestinal microbiota and permeability. Fermenting ingredients of diet, like fermentable oligosaccharides, disaccharides, monosaccharides and polyols (FODMAP), were also eliminated in some cases [96]. The application of the autoimmune protocol was motivated by the positive results obtained by the authors in patients with inflammatory bowel disease [97]. After 10 weeks of therapy, symptoms of the disease, measured by the Medical Symptoms Questionnaire, reduced from 92 to 29 points, and the quality of life measured by 36-Item Short-Form Health Survey improved significantly [96]. It is known that the quality of life of HT patients is reduced what might remain even after levothyroxine therapy [98]. There was no improvement in the thyroid function and antithyroid antibodies serum concentration, although the number of immune cells and high sensitivity $\mathrm{C}$ reactive protein, an inflammatory processes marker, decreased from 1.63 to $1.15 \mathrm{mg} / \mathrm{L}(-29 \%)$. As mentioned above, it is difficult to indicate what was responsible for the observed results, but it is important that dietary intervention and gluten exclusion did not affect thyroid function or serological results [96].

Another case study concerned 23-year-old woman with anorexia, ovarian failure, and multiple autoimmune diseases: HT, Addison's disease, and CD. AGFD was advised, combined with thyroid hormone therapy and corticosteroids. After three months, the need for thyroid replacement therapy decreased progressively. Thyroid functions, TSH and antithyroid titers improved, while comparing indicated parameters for 6, 12 and 18 months of therapy, although antiTPO at the end of the study was still increased [99]. Thyroid hormone replacement therapy and corticosteroids applied in the intervention was unable to assess whether gluten had any effect on the obtained results.

\section{CONCLUSIONS}

Studies conducted to-date do not support the claim that HT patients should eliminate gluten from their diet. Because of the limited number of study which have major limitations and ambiguous results, the elimination of gluten from the diet cannot be recommended. It is not known whether the gluten elimination in patients without $\mathrm{CD}$ and a positive anti-TPO titer may be beneficial, but it is known to be potentially harmful. On the other hand, patients with CD and suffering from thyroid autoimmunity, may support their treatment by an elimination diet, although studies regarding the potential improvement of their thyroid condition or reduction of its damage are equivocal. It was observed in a Polish study that a GFD improved the level of anti-TPO in a group of euthyroid HT patients without $\mathrm{CD}$, but with positive anti-tTG titers. There are some possible causes for a GFD or 
gluten foodstuffs consumption on the development or exacerbation of HT (Fig. 2). More studies are needed on the molecular mechanisms involved in the generation of autoantibodies. The conclusion of the presented review is consistent with the opinion of the POLSPEN, indicating that a GFD should not be recommended to HT patients without concurrent gluten-related diseases.

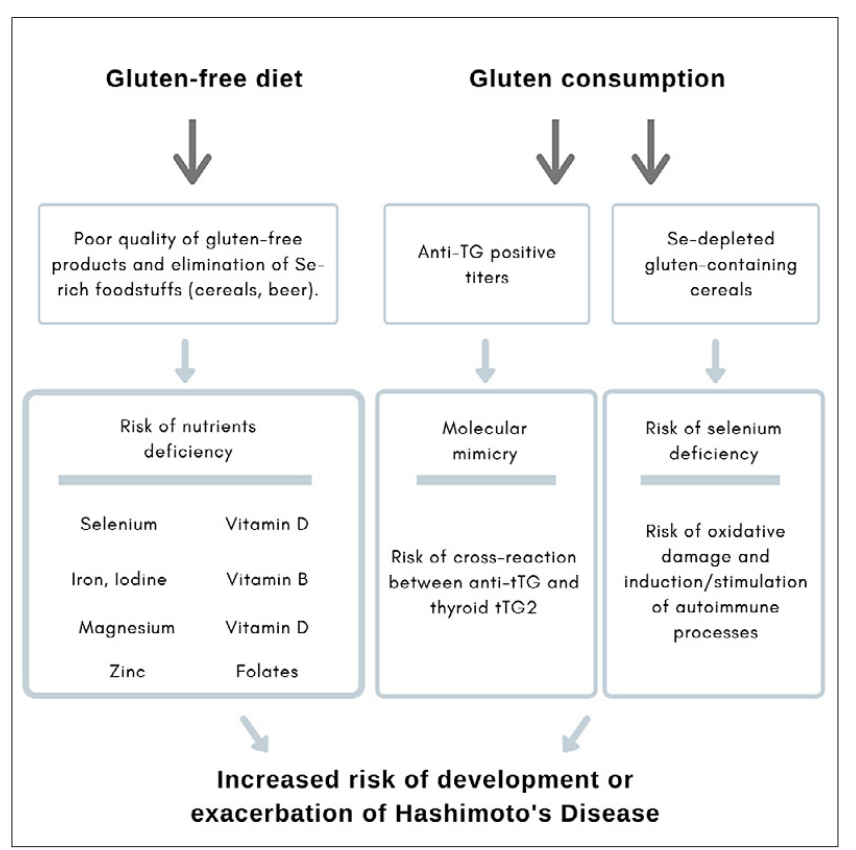

Figure 2. Possible relationship between gluten intake and HT

There are a few possible relationships between gluten intake and risk of HT development or exacerbation. A gluten-free diet when inadequate applied may cause nutritional deficiencies, which is often reported in HT patients. Moreover, if GFD relates to the elimination of selenium-rich cereals, that might be the most significant negative impact of GFD on thyroid health. On the other hand, if crops are grown on seleniumdepleted soil, gluten consumption may be associated with low Se intake and a high incidence of HT. Crops grown on soil rich in Se are a source of this compound in the diet. In this case, gluten consumption can be related to lower HT incidence. This claim is supported by a study in China [11]. A cross-reaction existing between tissue transglutaminase antibody (anti-tTG) and thyroid tissue transglutaminase 2 might be responsible for thyroid destruction in people with positive anti-tTG test results [15].

Diet therapy guidelines for dietitians. If a GFD is essential, a physician or dietitian should bear in mind that it is difficult to handle, and that it is associated with potential deficiencies, including magnesium and B vitamins [3-5]. In the case of magnesium, its deficiency may be responsible for some HT symptoms [6-8] and may be a part of the mitochondrial background for the disease $[6,100]$. In such cases, introducing an elimination diet may lead to an increased severity of the disease if the patient does not have adequate dietary support. Each patient should be guided properly regarding the importance of nutrition and the sources from which credible knowledge may be achieved, preferably by the dietitian.

Table 3. Summaries of recently published studies on HT patients regarding CD prevalence or CD-associated antibodies positivity

\begin{tabular}{lll}
\hline $\begin{array}{l}\text { Population screened } \\
\text { Country }\end{array}$ & $\begin{array}{c}\text { Prevalence of positive antibodies in tested vs control } \\
\text { group [\%] }\end{array}$ \\
\hline $\begin{array}{l}577 \text { anti-TPO positive cases vs } \\
\text { age and gender-matched control }\end{array}$ & $\begin{array}{l}\text { Anti-tTG positivity was detected at } 6.4 \% \text { vs } 3.3 \% \\
\text { children patients and } 7.4 \% \text { vs } 3.5 \% \text { in adult patients. } \\
\text { Anti-GAD positivity was detected in } 10.6 \% \text { and } 13.8 \% \\
\text { of child and adult patients vs 3.3\% and } 5 \% \text { in control } \\
\text { group. }\end{array}$ \\
\hline
\end{tabular}

$\begin{array}{ll}\begin{array}{l}\text { 914 autoimmune hypothyroid Jordan } \\ \text { patients }\end{array} \text { titers } & \text { (117/914) had IgA and IgG anti-EMA positive }\end{array}$

$40.2 \%$ anti-TPO positive cases had hypothyroidism vs $4.9 \%$ in the control group. In those $40.2 \%, 13.1 \%$ vs $0 \%$ had HT. The rest was SHT. Anti-tTG and anti-GAD antibodies level increased with anti-TPO.

87/117 underwent duodenal biopsy and 39/87 (44.8\%) had positive histological findings of CD which is $4.3 \%$ of CD prevalence in the studied group. If those who did not subject to duodenal biopsy underwent and had the same rate of $C D$, the rate would be $5.7 \%$.

$3 / 4$ of them (2.7\%) had biopsy-proved CD

\begin{tabular}{lcl}
\hline 111 HT vs 100 control & Brazil & $\begin{array}{l}\text { IgA-EMA was positive in 4/111 (3.6\%) HT patients vs } \\
\text { 0\% control }\end{array}$ \\
\hline $\begin{array}{l}\text { 53 AITD patients (not specified, } \\
\text { diagnosed based on increased } \\
\text { anti-TPO and anti-TG and altered }\end{array}$ & Brazil & $\begin{array}{l}5 / 53(9.3 \%) \text { had positive IgA-tTG or IgA-EMA titers, } \\
\text { none of them had both antibodies positive }\end{array}$
\end{tabular}

anti-TPO and anti-TG and altered TSH level).

499 hypothyroid patients $\quad$ USA Anti-tTG positivity detected in 10/499 (2\%)

\begin{tabular}{lll}
\hline $80 \mathrm{HT}$ patients & Turkey & IgA-anti-tTG found positive in 1/80 (1.25\%) \\
$\begin{array}{l}40 \mathrm{HT}, 42 \text { age-matched control } \\
\text { woman }\end{array}$ & Iran $\begin{array}{l}\text { IgG, IgA anti-tTG and IgG, IgA anti-gliadin, compared to } \\
\text { controls were increased in 15\% vs. 7\%, 22.5\% vs. 17\%, } \\
9,5 \% \text { vs. 5\%, and 15\% vs. 12\% participants }\end{array}$ \\
\hline $\begin{array}{l}757 \text { patients with AITDs (86.7\% } \\
\text { had HT) }\end{array}$ & Argentina & $\begin{array}{l}5 / 757(0.6 \%) \text { were previously affected with CD. 30/757 } \\
(3.9 \%) \text { patients were newly- diagnosed with CD. }\end{array}$ \\
\hline
\end{tabular}

Only 2/5 serologically- positive CD patients underwent upper digestive endoscopy, one of whom had duodenal [66] mucosa histological changes characteristic for CD

CD based on biopsy detected in 9/500 patients (1.8\%). The higher need for LT4 dose was detected in those with higher prevalence of $C D$.

Biopsy proved CD

Ordinal regression model showed that lgG anti-tTG and IgA anti-gliadin were significant predictors for antithyroid antibodies in $\mathrm{HT}$ had HT) (3.9\%) patients were newly- diagnosed with CD. 
Paulina Ihnatowicz, Paweł Wątor, Małgorzata Ewa Drywień. The importance of gluten exclusion in the management of Hashimoto's thyroiditis

Table 4. Summaries of recently published studies on CD patients regarding HT prevalence or HT-associated antibodies positivity

\begin{tabular}{|c|c|c|c|c|}
\hline Population screened & Country & $\begin{array}{l}\text { Prevalence of positive antibodies in tested vs control } \\
\text { group [\%] }\end{array}$ & Comment / other results & Ref. \\
\hline $335 \mathrm{CD}$ and 1695 control & Sweden & $\begin{array}{l}7.2 \%(24 / 335) \text { had elevated titers of TPOAb, compared } \\
\text { to } 2.8 \%(48 / 1695) \text { from control group }\end{array}$ & - & [107] \\
\hline 67 cases, children & Turkey & $\begin{array}{l}16.4 \% \text { cases became positive for antithyroid } \\
\text { antibodies } 2-3 \text { years after the diagnosis of } C D\end{array}$ & GFD did not affect thyroid antibodies positivity & [108] \\
\hline $\begin{array}{l}288 \text { untreated CD patients, } 250 \\
\text { controls }\end{array}$ & Iran & $\begin{array}{l}\text { In CD group, } 30 / 288(10.4 \%) \text { had hypothyroidism, } \\
5 / 288(1.7 \%) \text { had positive anti-TPO titers compared } \\
\text { to } 7 / 250(2.8 \%) \text { and } 1 / 250(0.4 \%) \text { in control group, } \\
\text { respectively. }\end{array}$ & $\begin{array}{l}\text { Thyroid disease (hyper-, hypothyroidism) prevalence was } \\
39 / 288(13.6 \%) \text { in CD patients and ( } 8 / 250) 3.2 \% \text { in control } \\
\text { group. Thyroid disease prevalence was } 4 \text {-fold higher in } \\
\text { CD patients than in control group }\end{array}$ & [109] \\
\hline $\begin{array}{l}100 \text { patients (1-12-years-old) } \\
\text { with } C D\end{array}$ & Pakistan & $\begin{array}{l}14 / 100(1.4 \%) \text { had autoimmune thyroiditis at } \\
\text { enrollment, and a further } 6 / 86(7 \%) \text { were later } \\
\text { diagnosed at follow-up period of } 1 \text { year. }\end{array}$ & $\begin{array}{l}\text { Autoimmune thyroiditis frequency was } 20 \% \text { over a } \\
\text { one year period follow-up. Patients were on GFD with } \\
\text { poor compliance ( } 52 \%) .4 / 20 \text { ( } 28.6 \% \text { ) of autoimmune } \\
\text { thyroiditis patients improved on GFD. } 3 / 6 \text { ( } 50 \% \text { ) } \\
\text { autoimmune thyroiditis patients at diagnosis became } \\
\text { hypothyroid and all were non-compliant. }\end{array}$ & [110] \\
\hline 74 untreated $C D$ patients & Indian & $20 / 74(27 \%)$ were positive for anti-TPO antibody. & $\begin{array}{l}14 / 74(18.9 \%) \text { had autoimmune, clinical or subclinical } \\
\text { hypothyroidism }\end{array}$ & [112] \\
\hline $\begin{array}{l}92 \mathrm{CD} \text { patients, } 237 \text { healthy } \\
\text { control group }\end{array}$ & Italy & $11 / 92(12 \%)$ were positive anti-TPO titers & $\begin{array}{l}\text { One-third of adult CD patients at diagnosis were positive } \\
\text { for at least organ-specific autoantibody (thyroid, } \\
\text { pancreas, gastric and adrenal). }\end{array}$ & [113] \\
\hline $\begin{array}{l}64 \text { CD children, } 143 \text { control } \\
\text { group on GFD diet from } 3 \\
\text { months to } 15 \text { years (median } 4 \\
\text { years) }\end{array}$ & Turkey & $\begin{array}{l}8 / 64(12.5 \%) \text { compared to } 6 / 143(4.2 \%) \text { had } \\
\text { autoimmune thyroid disease. }\end{array}$ & $\begin{array}{l}9.3 \% \text { vs } 2.8,3.58 \text { vs } 3.95 \mathrm{ml}, 12.5 \% \text { vs } 2.1 \%, 25 \% \text { vs } 4.2 \% \\
\text { of patients, compared to control had abnormalities in } \\
\text { thyroid funtions, mean thyroid volume, parenchymal } \\
\text { heterogeneity, incidence of thyroid nodues, respectively. }\end{array}$ & [114] \\
\hline 107 CD children & Iraq & $3 / 107$ (2.8\%) had concomitant AIT & $\begin{array}{l}\text { No significant association between CD groups with AIT } \\
\text { were found }\end{array}$ & [115] \\
\hline
\end{tabular}

\section{REFERENCES}

1. Szostak-Węgierek D, Bednarczuk T, Respondek W, Traczyk I, Cukrowska B, Ostrowska L, et al. The validity of using a gluten-free diet in Hashimoto's disease: the position of the Expert Group of the Medical Dietetics Section of the Polish Society of Parenteral Nutrition and Enteral Metabolism (POLSPEN). Postępy Żywienia Klinicznego. 2018; 47: 33-47. [in Polish]

2. Janatuinen EK, Kemppainen TA, Julkunen RJ, Kosma VM, Mäki M, Heikkinen M, Uusitupa MI. No harm from five year ingestion of oats in coeliac disease. Gut. 2002; 50: 332-325. http://dx.doi.org/10.1136/ gut.50.3.332

3. Myszkowska-Ryciak J, Harton A, Gajewska D. Analysis of the nutritional value of the cost of a gluten-free diet compared to a standard food ration. Med Og Nauk Zdr. 2015; 21: 312-316. https:// doi.org/10.5604/20834543.1165359. [in Polish]

4. Rybicka I, Gliszczyńska-Świgło A. Nutrient deficiencies in a gluten-free diet. Probl Hig Epidemiol. 2016; 97: 183-186. [in Polish]

5. Niland B, Cash BD. Health Benefits and Adverse Effects of a GlutenFree Diet in Non-Celiac Disease Patients. Gastroenterol Hepatol (NY). 2018; 14(2): 82-91. PMC5866307

6. Moncayo R, Moncayo H. Exploring the aspect of psychosomatics in hypothyroidism: The WOMED model of body-mind interactions based on musculoskeletal changes, psychological stressors, and low levels of magnesium. Woman - Psychosom Gynaecol Obstet. 2014; 1: 1-11. http://dx.doi.org/10.1016/j.woman.2014.02.001

7. Moncayo R, Moncayo H. The WOMED model of benign thyroid disease: Acquired magnesium deficiency due to physical and psychological stressors relates to dysfunction of oxidative phosphorylation. BBA Clin. 2014; 3: 44-64. https://doi.org/10.1016/j.bbacli.2014.11.002

8. Moncayo R, Moncayo H. Proof of concept of the WOMED model of benign thyroid disease: Restitution of thyroid morphology after correction of physical and psychological stressors and magnesium supplementation. BBA Clin. 2014; 3: 113-122. https://doi.org/10.1016/j. bbacli.2014.12.005

9. Ihnatowicz P, Drywień M, Wator P, Wojsiat J. The importance of nutritional factors and dietary management of Hashimoto's thyroiditis. Ann Agric Environ Med. 2020; 27(2): 184-193. https:// doi.org/10.26444/aaem/112331
10. Schomburg L. Selenium, selenoproteins and the thyroid gland: interactions in health and disease. Nat Rev Endocrinol. 2011; 8(3): 160-171. doi: 10.1038/nrendo.2011.174

11. Wu Q, Rayman MP, Lv H, et al. Low Population Selenium Status Is Associated With Increased Prevalence of Thyroid Disease. J Clin Endocrinol Metab. 2015; 100(11): 4037-4047. doi: 10.1210/jc.2015-2222

12. Laurberg P, Andersen S, Pedersen IB, Knudsen N, Carlé A. Prevention of autoimmune hypothyroidism by modifying iodine intake and the use of tobacco and alcohol is manoeuvring between Scylla and Charybdis. Hormones (Athens). 2013; 12(1): 30-38. doi: 10.1007/BF03401284

13. Carlé A, Pedersen IB, Knudsen N, et al. Moderate alcohol consumption may protect against overt autoimmune hypothyroidism: a populationbased case-control study. Eur J Endocrinol. 2012; 167(4): 483-490. doi: 10.1530/EJE-12-0356

14. Adadi P, Barakova NV, Muravyov KY, Krivoshapkina EF. Designing selenium functional foods and beverages: A review. Food Res Int. 2019; 120: 708-725. doi: 10.1016/j.foodres.2018.11.029

15. Naiyer AJ, Shah J, Hernandez L, Kim SY, Ciaccio EJ, Cheng J, Manavalan S, Bhagat G, Green PH. Tissue transglutaminase antibodies in individuals with celiac disease bind to thyroid follicles and extracellular matrix and may contribute to thyroid dysfunction. Thyroid 2008; 18: 1171-1178. https://doi.org/10.1089/thy.2008.0110

16. Roy A, Laszkowska M, Sundström J, Lebwohl B, Green PH, Kämpe O, Ludvigsson JF. Prevalence of Celiac Disease in Patients with Autoimmune Thyroid Disease: A Meta-Analysis. Thyroid 2016; 26: 880-890. https://doi.org/10.1089/thy.2016.0108

17. Husby S, Koletzko S, Korponay-Szabó IR, Mearin ML, Phillips A, Shamir R, et al. ESPGHAN Working Group on Coeliac Disease Diagnosis; ESPGHAN Gastroenterology Committee; European Society for Pediatric Gastroenterology, Hepatology, and Nutrition. European Society for Pediatric Gastroenterology, Hepatology, and Nutrition guidelines for the diagnosis of coeliac disease. J Pediatr Gastroenterol Nutr. 2012; 54: 136-160. https://doi.org/10.1097/ MPG.0b013e31821a23d0

18. Sari S, Yesilkaya E, Egritas O, Bideci A, Dalgic B. Prevalence of celiac disease in Turkish children with autoimmune thyroiditis. Dig Dis Sci. 2009; 54: 830-832. https://doi.org/10.1007/s10620-008-0437-1

19. Marwaha RK, Garg MK, Tandon N, Kanwar R, Narang A, Sastry A, Saberwal A, Bhadra K. Glutamic acid decarboxylase (anti-GAD) \& 
tissue transglutaminase (anti-TTG) antibodies in patients with thyroid autoimmunity. Indian J Med Res. 2013; 137: 82-86.

20. Guliter S, Yakaryilmaz F, Ozkurt Z, Ersoy R, Ucardag D, Atasoy P. Prevalence of coeliac disease in patients with autoimmune thyroiditis in a Turkish population. World J Gastroenterol. 2007; 13: 1599-1601.

21. Riseh SH, Farhang AM, Mobasser M, Jafarabadi AM. The Relationship between Thyroid Hormones, Antithyroid Antibodies, Anti-Tissue Transglutaminase and Anti-Gliadin Antibodies in Patients with Hashimoto's Thyroiditis. Acta Endocrinol (Buchar). 2017; 13: 174-179. https://doi.org/10.4183/aeb.2017.174

22. Kowalska E, Wasowska-Królikowska K, Toporowska-Kowalska E. Estimation of antithyroid antibodies occurrence in children with coeliac disease. Med Sci Monit. 2000; 6: 719-721.

23. Meloni A, Mandas C, Jores RD, Congia M. Prevalence of autoimmune thyroiditis in children with celiac disease and effect of gluten withdrawal. J Pediatr. 2009; 155: 51-55, 55.e1. https://doi.org/10.1016/j. jpeds.2009.01.013

24. Hakanen M, Luotola K, Salmi J, Laippala P, Kaukinen K, Collin P. Clinical and subclinical autoimmune thyroid disease in adult celiac disease. Dig Dis Sci. 2001; 46: 2631-2635.

25. Velluzzi F, Caradonna A, Boy MF, Pinna MA, Cabula R, Lai MA Piras E, Corda G, Mossa P, Atzeni F, et al. Thyroid and celiac disease: clinical, serological, and echographic study. Am J Gastroenterol. 1998; 93: 976-979.

26. Carta MG, Hardoy MC, Boi MF, Mariotti S, Carpiniello B, Usai P. Association between panic disorder, major depressive disorder and celiac disease: a possible role of thyroid autoimmunity. J Psychosom Res 2002; 53: 789-793.

27. Collin P, Reunala T, Pukkala E, Laippala P, Keyriläinen O, Pasternack A. Coeliac disease-associated disorders and survival. Gut 1994; 35: $1215-1218$.

28. Guariso G, Conte S, Presotto F, et al. Clinical, subclinical and potential autoimmune diseases in an Italian population of children with coeliac disease. Aliment Pharmacol Ther. 2007; 26(10): 1409-1417. doi: 10.1111/j.1365-2036.2007.03526.x

29. Kumar R, Saraf S. Autoimmune thyroiditis with fluctuating antibodies Endocrine Abstracts. 2019; 62 CB7 | doi: 10.1530/endoabs.62.CB7

30. Kahaly GJ, Frommer L, Schuppan D. Celiac disease and endocrine autoimmunity - the genetic link. Autoimmun Rev. 2018; 17: 1169-1175. https://doi.org/10.1016/j.autrev.2018.05.013

31. Stazi AV, Trinti B. Selenium status and over-expression of interleukin-15 in celiac disease and autoimmune thyroid disease. Ann Ist Super Sanita. 2010; 46: 389-399. https://doi.org/10.4415/ANN_10_04_06

32. Ambroziak U, Hybsier S, Shahnazaryan U, Krasnodębska-Kiljańska M, Rijntjes E, Bartoszewicz Z, Bednarczuk T, Schomburg L. Severe selenium deficits in pregnant women irrespective of autoimmune thyroid disease in an area with marginal selenium intake. J Trace Elem Med Biol. 2017; 44: 186-191. https://doi.org/10.1016/j.jtemb.2017.08.005

33. Ihnatowicz P, Wątor P, Drywień ME. Supplementation in Autoimmune Thyroid Hashimoto's Disease. Vitamin D and Selenium. J Food Nutr Res. 2019; 7: 584-591. https://doi.org/10.12691/jfnr-7-8-6

34. Markiewicz-Zukowska R, Naliwajko SK, Bartosiuk E, Sawicka E, Omeljaniuk WJ, Borawska MH. Zawartość witamin w dietach kobiet z chorobą Hashimoto. Bromat Chem Toksykol. 2011, XLIV: 539-543.

35. Krysiak, R, Szkróbka W, Okopień, B. The Effect of Gluten-Free Diet on Thyroid Autoimmunity in Drug-Naïve Women with Hashimoto's Thyroiditis: A Pilot Study. Exp Clin Endocrinol Diabetes. 2019; 127: 417-422. https://doi.org/10.1055/a-0653-7108

36. Lizis-Kolus K. Ocena wpływu niedoboru witaminy D na przebieg choroby Hashimoto u chorych w województwie świętokrzyskim. Praca doktorska. Kraków: Uniwersytet Jagielloński; 2015. [in Polish]

37. Krysiak R, Szkróbka W, Okopień B. The effect of vitamin D and selenomethionine on thyroid antibody titers, hypothalamic-pituitarythyroid axis activity and thyroid function tests in men with Hashimoto's thyroiditis: A pilot study. Pharmacol Rep. 2018; 71: 243-247. https:// doi.org/10.1016/j.pharep.2018.10.012

38. Assa A, Frenkel-Nir Y, Tzur D, et al. Large population study shows that adolescents with celiac disease have an increased risk of multiple autoimmune and nonautoimmune comorbidities. Acta Paediatr. 2017; 106: 967-972. https://doi.org/10.1111/apa.13808

39. Hess SY, Zimmermann MB, Arnold M, Langhans W, Hurrell RF. Iron deficiency anemia reduces thyroid peroxidase activity in rats. J Nutr. 2002; 132(7): 1951-5. PMID: 12097675. https://doi.org/10.1093/ jn/132.7.1951

40. Dahiya K, Verma M, Dhankhar R, et al. Thyroid profile and iron metabolism: mutual relationship in hypothyroidism. Biomed Res (India). 2016; 27: 1212-1215.
41. Wopereis DM, Du Puy RS, van Heemst D, et al. The Relation Between Thyroid Function and Anemia: A Pooled Analysis of Individual Participant Data. J Clin Endocrinol Metab. 2018; 103: 3658-3667. https://doi.org/10.1210/jc.2018-00481

42. Khatiwada S, Gelal B, Baral N, et al. Association between iron status and thyroid function in Nepalese children. Thyroid Res. 2016; 9: 2. https://doi.org/10.1186/s13044-016-0031-0

43. Shukla A, Agarwal S, Gupta A, et al. Relationship between Body Iron Status and Thyroid Profile in an Adult Population: A Hospital Based Study. Natl Lab Med. 2017; 6: BO01-BO03. https://doi.org/10.7860/ NJLM/2017/24065:2204

44. Rooks MG, Garrett WS. Gut microbiota, metabolites and host immunity. Nat Rev Immunol. 2016; 16: 341-352. https://doi. org/10.1038/nri.2016.42

45. Zhang J, Zhang F, Zhao C, et al. Dysbiosis of the gut microbiome is associated with thyroid cancer and thyroid nodules and correlated with clinical index of thyroid function. Endocrine. 2019; 64: 564-574. https://doi.org/10.1007/s12020-018-1831-x

46. Ishaq HM, Mohammad IS, Guo H, et al. Molecular estimation of alteration in intestinal microbial composition in Hashimoto's thyroiditis patients. Biomed Pharmacother. 2017; 95: 865-874. https:// doi.org/10.1016/j.biopha.2017.08.101

47. Virili C, Fallahi P, Antonelli A, et al. Gut microbiota and Hashimoto's thyroiditis. Rev Endocr Metab Disord. 2018; 19: 293-300. https://doi. org/10.1007/s11154-018-9467-y

48. Fasano A. Zonulin and its regulation of intestinal barrier function: the biological door to inflammation, autoimmunity, and cancer. Physiol Rev. 2011 Jan; 91(1): 151-75. doi: 10.1152/physrev.00003.2008. PMID: 21248165.

49. Küçükemre Aydın B, Yıldız M, Akgün A, et al. Children with Hashimoto's Thyroiditis Have Increased Intestinal Permeability: Results of a Pilot Study. J Clin Res Pediatr Endocrinol. Epub. 2020; 12(3): 303-307. https://doi.org/10.4274/jcrpe. galenos.2020.2019.0186

50. Fasano, A. Intestinal Permeability and its Regulation by Zonulin: Diagnostic and Therapeutic Implications. Clin Gastroenterol Hepatol. 2012; 10: 1096-1100. https://doi.org/10.1016/j.cgh.2012.08.012

51. Vancamelbeke $M$, Vermeire $S$. The intestinal barrier: a fundamental role in health and disease. Expert Rev Gastroenterol Hepatol. 2017; 11: 821-834. https://doi.org/10.1080/17474124.2017.1343143

52. Twito O, Shapiro Y, Golan-Cohen A. et al. Anti-thyroid antibodies, parietal cell antibodies and tissue transglutaminase antibodies in patients with autoimmune thyroid disease. Arch Med Sci. 2018; 14: 516-520. https://doi.org/10.5114/aoms.2016.58743

53. Rose NR. Insight into Mechanisms of Autoimmune Disease Based on Clinical Findings. In: Sudhir P, editor. Autoimmune Reactions. Totowa, New Jersey: Humana Press; 1999. p. 5-14. https://doi.org/10.1007/9781-4612-1610-0_2

54. Siomkajło M, Dybko J, Daroszewski J. Regulatory lymphocytes in thyroid orbitopathy and autoimmune thyroid diseases. Postepy Hig Med Dosw. (online). 2016; 70(0): 1378-1388. https://doi. org/10.5604/17322693.1227644

55. Theofilopoulos AN, Kono DH, Baccala R. The multiple pathways to autoimmunity. Nat Immunol. 2017; 18(7): 716-724. https://doi. org/10.1038/ni.3731

56. Szaflarska A, Rutkowska-Zapała M, Kowalczyk D. Immune tolerance mechanisms - brief review. Przegląd Lekarski. 2015; 72(12): 765-769.

57. Paul S. Diversity of Immunological Defects in Autoimmune Diseases. In: Paul S, editor. Autoimmune Reactions. Totowa, New Jersey: Humana Press; 1999. p. 1-4. https://doi.org/10.1007/978-1-4612-1610

58. Peng S, Li C, Wang X, et al. Increased Toll-Like Receptors Activity and TLR Ligands in Patients with Autoimmune Thyroid Diseases. Front Immunol. 2016; 7: 578. https://doi.org/10.3389/fimmu.2016.00578

59. Worthington J, Silman AJ. Genetic control of autoimmunity, lessons from twin studies. Clin Exp Immunol. 1995; 101(3): 390-392. https:// doi.org/10.1111/j.1365-2249.1995.tb03124.x

60. Brix TH, Hegedüs L. Twin studies as a model for exploring the aetiology of autoimmune thyroid disease. Clin Endocrinol (Oxf). 2012; 76(4): 457-64. https://doi.org/10.1111/j.1365-2265.2011.04318.x

61. Rochester JR, Bolden AL. Bisphenol S and F: A Systematic Review and Comparison of the Hormonal Activity of Bisphenol A Substitutes. Environ Health Perspect. 2015; 123(7): 643-50. https://doi.org/10.1289/ ehp.1408989

62. Benvenga S, Elia G, Ragusa F, et al. Endocrine disruptors and thyroid autoimmunity. Best Pract Res Clin Endocrinol Metab. 2020; 34(1): 101377. https://doi.org/10.1289/ehp.1408989.10.1016/j. beem.2020.101377 
63. Ferrari SM, Fallahi P, Antonelli A, Benvenga S. Environmental Issues in Thyroid Diseases. Front Endocrinol. 2017; 8: 50. https://doi. org/10.3389/fendo.2017.00050

64. Aaron L, Torsten M, Patricia W. Autoimmunity in celiac disease: Extra-intestinal manifestations. Autoimmun Rev. 2019; 18(3): 241-246. https://doi.org/10.1016/j.autrev.2018.09.010

65. Ventura A, Neri E, Ughi C, et al. Gluten-dependent diabetes-related and thyroid-related autoantibodies in patients with celiac disease. J Pediatr. 2000; 137: 263-265. https://doi.org/10.1067/mpd.2000.107160.

66. Oderda G, Rapa A, Zavallone A, et al. Thyroid autoimmunity in childhood celiac disease. J Pediatr Gastroenterol Nutr. 2002; 35: 704 705. https://doi.org/10.1097/00005176-200211000-00023

67. Toscano V, Conti FG, Anastasi E, et al. Importance of gluten in the induction of endocrine autoantibodies and organ dysfunction in adolescent celiac patients. Am J Gastroenterol. 2000; 95: 1742-1748. https://10.1111/j.1572-0241.2000.02187.x

68. Magazzu G, De Luca F, Benvenga S, et al. Hypothyroidie biologique transitoire chez un nourrisson porteur d'une maladie coeliaque. Pediatrie 1983; 38(4): 249-252.

69. Cosnes J, Cellier C, Viola S, et al. Groupe D'Etude et de Recherche Sur la MaladieCoeliaque. Incidence of autoimmune diseases in celiac disease: protective effect of the gluten-free diet. Clin Gastroentero Hepatol. 2008; 6(7): 753-8. https://doi.org/10.1016/j.cgh.2007.12.022

70. Ansaldi, N, Palmas T, Corrias A, et al. Autoimmune thyroid disease and celiac disease in children. J Pediatr Gastroenterol Nutr. 2003; 37(1): 63-6. https://doi.org/10.1097/00005176-200307000-00010

71. Diamanti A, Ferretti F, Guglielmi R, et al. Thyroid autoimmunity in children with coeliac disease: a prospective survey. Arch Dis Child. 2011;96(11): 1038-41.https://doi.org/10.1136/archdischild-2011-300595

72. Metso S, Hyytiä-Ilmonen H, Kaukinen K, et al. Gluten-free diet and autoimmune thyroiditis in patients with celiac disease. A prospective controlled study. Scand J Gastroenterol. 2012; 47(1): 43-8. https://doi. org/10.3109/00365521.2011.639084

73. Minelli R, Gaiani F, Kayali S, et al. Thyroid and celiac disease in pediatric age: a literature review. Acta Biomed. 2018; 89(9-S): 11-16. https://doi.org/10.23750/abm.v89i9-S.7872

74. Cassio A, Ricci G, Baronio F, et al. Long-term clinical significance of thyroid autoimmunity in children with celiac disease. J Pediatr. 2010; 156(2): 292-295. https://doi.org/10.1016/j.jpeds.2009.08.047

75. Sategna-Guidetti C, Volta U, Ciacci C, Usai P, Carlino A, De Franceschi L, Camera A, Pelli A, Brossa C. Prevalence of thyroid disorders in untreated adult celiac disease patients and effect of gluten withdrawal: an Italian multicenter study. Am J Gastroenterol. 2001; 96(3): 751-7. https://doi.org/10.1111/j.1572-0241.2001.03617.x

76. Rasheed J, Hassan R, Khalid M, et al. Frequency of autoimmune thyroiditis in children with Celiac disease and effect of gluten free diet. Pak J Med Sci. 2020; 36(6): 1280-1284. https://doi.org/10.12669/ pjms.36.6.2226

77. Krysiak R, Kowalcze K, Okopien B. The effect of vitamin D on thyroid autoimmunity in non-lactating women with postpartum thyroiditis. Eur J Clin Nutr. 2016; 70(5): 637-9. https://doi.org/10.1038/ ejcn.2015.214

78. Krysiak R, Okopien B. The effect of levothyroxine and selenomethionine on lymphocyte and monocyte cytokine release in women with Hashimoto's thyroiditis. J Clin Endocrinol Metab. 2011; 96(7): 2206-15. https://doi.org/10.1210/jc.2010-2986

79. Krysiak R, Kowalcze K, Okopien B. Selenomethionine potentiates the impact of vitamin D on thyroid autoimmunity in euthyroid women with Hashimoto's thyroiditis and low vitamin D status. Pharmacol Rep. 2019; 71(2): 367-373. https://doi.org/10.1016/j.pharep.2018.12.006

80. Kłapcińska B, Poprzecki S, Danch A, et al. Selenium levels in blood of Upper Silesian population: evidence of suboptimal selenium status in a significant percentage of the population. Biol Trace Elem Res. 2005; 108(1-3): 1-15. https://doi.org/10.1385/BTER:108:1-3:001

81. Antvorskov JC, Fundova P, Buschard K, et al. Dietary gluten alters the balance of pro-inflammatory and anti-inflammatory cytokines in $\mathrm{T}$ cells of BALB/c mice. Immunology. 2013; 138(1): 23-33. https://doi. org/10.1111/imm.12007

82. Street ME, Volta C, Ziveri MA, et al. Changes and relationships of IGFS and IGFBPS and cytokines in coeliac disease at diagnosis and on gluten-free diet. Clin Endocrinol (Oxf). 2008; 68(1): 22-28. http:// doi.org/10.1111/j.1365-2265.2007.02992.x

83. Arrigo T, Wasniewska M, Crisafulli G, et al. Subclinical hypothyroidism: the state of the art. J Endocrinol Invest. 2008; 31(1): 79-84. https://doi. org/.10.1007-BF03345571

84. Chaker L, Bianco AC, Jonklaas J, et al. Hypothyroidism. Lancet. 2017; 390: 1550-1562. https://doi.org/10.1016/S0140-6736(17)30703-1
85. Asimi ZV, Hadzovic-Dzuvo A, Tawil DA. The effect of selenium supplementation and gluten-free diet in patients with subclinical hypothyroidism affected by autoimmune thyroiditis. Endocrine Abstracts. 2020; 70: AEP906. https://doi.org/10.1530/endoabs.70.AEP906

86. Avard N, Grand SJ. A case report of a novel, integrative approach to Hashimoto's thyroiditis with unexpected results. Adv Integr Med. 2018; 5(2): 75-79. https:/doi.org/10.1016/j.aimed.2018.03.003

87. Seshadri D, De D. Nails in nutritional deficiencies. Indian J Dermatol Venereol Leprol. 2012; 78(3): 237-41. https://doi.org/10.4103/03786323.95437

88. Coppedè F. One-carbon metabolism and Alzheimer's disease: focus on epigenetics. Curr Genomics. 2010; 11(4): 246-60. https://doi. org/10.2174/138920210791233090

89. Greer JM, McCombe PA. The role of epigenetic mechanisms and processes in autoimmune disorders. Biologics. 2012; 6: 307-27. https:// doi.org/10.2147/BTT.S24067

90. Arakawa $Y$, Watanabe $M$, Inoue $N$, et al. Association of polymorphisms in DNMT1, DNMT3A, DNMT3B, MTHFR and MTRR genes with global DNA methylation levels and prognosis of autoimmune thyroid disease. Clin Exp Immunol. 2012; 170(2): 194-201. https:// doi.org/10.1111/j.1365-2249.2012.04646.x

91. Cai TT, Zhang J, Wang X, et al. Gene-gene and gene-sex epistatic interactions of DNMT1, DNMT3A and DNMT3B in autoimmune thyroid disease. Endocr J. 2016; 30; 63(7): 643-653. https://doi. org/10.1507/endocri.EJ15-0596

92. Suarez-Alvarez B, Rodriguez RM, Fraga MF, et al. DNA methylation: a promising landscape for immune system-related diseases. Trends Genet. 2012; 28(10): 506-14. https://doi.org/10.1016/j.tig.2012.06.005

93. Mu Q, Kirby J, Reilly CM, et al. Leaky Gut As a Danger Signal for Autoimmune Diseases. Front Immunol. 2017; 8: 598. https://doi. org/10.3389/fimmu.2017.00598

94. Higuchi BS, Rodrigues N, Gonzaga MI, et al. Intestinal Dysbiosis in Autoimmune Diabetes Is Correlated With Poor Glycemic Control and Increased Interleukin-6: A Pilot Study. Front Immunol. 2018; 9: 1689. https://doi.org/10.3389/fimmu.2018.01689

95. Mirhosseini N, Brunel L, Muscogiuri G, et al. Physiological serum 25-hydroxyvitamin D concentrations are associated with improved thyroid function-observations from a community-based program. Endocrine. 2017; 58(3): 563-573. https://doi.org/10.1007/s12020-0171450-y

96. Abbott RD, Sadowski A, Alt AG. Efficacy of the Autoimmune Protocol Diet as Part of a Multi-disciplinary, Supported Lifestyle Intervention for Hashimoto's Thyroiditis. Cureus. 2019; 11(4): e4556. https://doi. org/10.7759/cureus.4556

97. Konijeti GG, Kim N, Lewis JD, et al. Efficacy of the Autoimmune Protocol Diet for Inflammatory Bowel Disease. Inflamm Bowel Dis. 2017; 23(11): 2054-2060. https://doi.org/10.1097/MIB.0000000000001221

98. Winther KH, Cramon P, Watt T, et al. Disease-Specific as Well as Generic Quality of Life Is Widely Impacted in Autoimmune Hypothyroidism and Improves during the First Six Months of Levothyroxine Therapy. PLoS One. 2016; 11(6): e0156925. https://doi. org/10.1371/journal.pone.0156925

99. Valentino R, Savastano S, Tomaselli AP. Unusual association of thyroiditis, Addison's disease, ovarian failure and celiac disease in a young woman. J Endocrinol Invest. 1999; 22(5): 390-4. https:/doi. org/10.1007/BF03343578

100. Moncayo R, Moncayo H. Applying a systems approach to thyroid physiology: Looking at the whole with a mitochondrial perspective instead of judging single TSH values or why we should know more about mitochondria to understand metabolism. BBA Clin. 2017; 7: 127-140. https://doi.org/10.1016/j.bbacli.2017.03.004

101. Farahid OH, Khawaja N, Shennak MM, et al. Prevalence of coeliac disease among adult patients with autoimmune hypothyroidism in Jordan. East Mediterr Health J. 2014; 20(1): 51-5.

102. Teixeira LM, Nisihara R, da Rosa Utiyama SR, et al. Screening of celiac disease in patients with autoimmune thyroid disease from Southern Brazil. Arq Bras Endocrinol Metab. 2014; 58(6). http://dx.doi. org/10.1590/0004-2730000003003

103. Zubarik R, Ganguly E, Nathan M, Vecchio J. Celiac disease detection in hypothyroid patients requiring elevated thyroid supplementation: A prospective cohort study. Eur J Intern Med. 2015; 26(10): 825-9. https://doi.org/10.1016/j.ejim.2015.09.011

104. Tuhan H, Işık S, Abacı A, et al. Celiac disease in children and adolescents with Hashimoto Thyroiditis. Turk Pediatri Ars. 2016; 51(2): 100-5. https://doi.org/10.5152/TurkPediatriArs.2016.3566

105. Gil M, Aparicio MM, Ercoli V, et al. Prevalence of celiac disease in autoimmune thyroid diseases, and its associaton with other 
autoimmune disesases: a single center study in Argentina. Endocrine Abstracts. 2019; 63: P38. https://doi.org/10.1530/endoabs.63.P384

106. Van der Pals M, Ivarsson A, Norström F, Högberg L, Svensson J, Carlsson A. Prevalence of thyroid autoimmunity in children with celiac disease compared to healthy 12 -year olds. Autoimmune Dis. 2014; 2014: 417356. https://doi.org/10.1155/2014/417356

107. Kalyoncu D, Urganci N. Antithyroid antibodies and thyroid function in pediatric patients with celiac disease. Int J Endocrinol. 2015; 2015: 276575. https://doi.org/10.1155/2015/276575

108. Baharvand P, Hormozi M, Aaliehpour A. Comparison of thyroid disease prevalence in patients with celiac disease and controls. Gastroenterol Hepatol Bed Bench. 2020; 13(1): 44-49.

109. Rasheed J, Hassan R, Khalid M, Zafar F. Frequency of autoimmune thyroiditis in children with Celiac disease and effect of gluten free diet. Pak J Med Sci. 2020; 36(6): 1280-1284. https://doi.org/10.12669/ pjms.36.6.2226

110. Mitrogiorgou M, Karachaliou F, Karalexi M, et al. Celiac disease and endocrine autoimmunity in children and adolescents. ESPE Abstracts. 2019; 92: P2-214.
111. Gupta V, Singh A, Khadgawat R, et al. The spectrum of clinical and subclinical endocrinopathies in treatment-naïve patients with celiac disease. Indian J Gastroenterol. 2019; 38(6): 518-526. https://doi. org/10.1007/s12664-019-01006-w

112. Tiberti C, Panimolle F, Borghini R, et al. Type 1 diabetes, thyroid, gastric and adrenal humoral autoantibodies are present altogether in almost one third of adult celiac patients at diagnosis, with a higher frequency than children and adolescent celiac patients. Scand J Gastroenterol. 2020; 55(5): 549-554. https://doi.org/10.1080/003655 21.2020 .1754898

113. Şahin, Şükrü, Şahin FD. Autoimmune Thyroid Disease, Thyroid Functions, and Thyroid Ultrasonography in Pediatric Celiac Disease. Med Sci Discover. 2020; 7(11): 680-683. https://doi.org/10.36472/ msd.v7i11.432

114. Khalaf BS. Association of Autoimmune Thyroiditis and Type 1 Diabetes Mellitus With Severity of Children with Celiac Disease. Indian J Forensic Med Toxicol. 2020; 14(1). https://doi.org/10.37506/ v14/i1/2020/ijfmt/192996 